\title{
Online Home Schooling: Are Parents Ready? Lessons from the Corona Virus Disease Induced Lock Down
}

DOI: https://doi.org/10.47175/rielsj.v1i2.81

\section{| Gwendoline Vusumuzi Nani $^{1}$ | Lwazi Sibanda ${ }^{2}$ |}

\author{
${ }^{1}$ Graduate School of Business, \\ National University of Science \\ and Technology, Bulawayo, \\ Zimbabwe \\ ${ }^{2}$ Department of Science, \\ Mathematics and Technology \\ Education, National University \\ of Science and Technology, \\ Bulawayo, Zimbabwe \\ ${ }^{1}$ gwendoline.nani@nust.ac.zw / \\ gweni.nnani@gmail.com \\ 2/wazi.sibanda@nust.ac.zw
}

\begin{abstract}
The outbreak of the corona virus disease (COVID-19) in China around December 2019 led to the premature closure of schools globally. This was done to ensure reduced transmission of the disease. Due to the indefinite level two lockdown in Zimbabwe, schools remain closed. This has led to online home schooling, where schools send work to parents who conduct and monitor the lessons on their behalf. This study sought to find out the experiences and readiness of parents in Bulawayo Metropolitan Province, Zimbabwe, who were expected to conduct lessons online. The study which is situated in the interpretive paradigm and qualitative approach collected data from ten purposively selected parents as key informants. Qualitative data was collected using emailed open-ended questionnaires in compliance with COVID-19 regulations. Results revealed that parents found it difficult to conduct online lessons due to costly data, lack of expert knowledge and teaching pedagogy, unclear instructions from teachers, unavailable or shared gadgets at home and poor internet connectivity. Schools were also said to be piling up work, disregarding parents' other responsibilities. Conclusions drawn were that most of the parents were not ready for online home schooling although they perceived the exercise to be beneficial. Recommendations were that schools should conduct training sessions for staff and parents, have formal feedback sessions and exercise flexibility for execution and submission of work and continue online lessons post COVID-19. Further research could be conducted to find out learners' perceptions of online home schooling.

KEYWORDS

Contingency plans; COVID-19; online lessons.
\end{abstract}

\section{INTRODUCTION}

According to Kazunga (2020), the corona virus disease (COVID-19) which was first detected in China towards the end of 2019, has since spread across the world. To date, about 8. 92 million people around the world have been infected with hundreds of thousands having lost their lives. Keogh-Brown, McDonald, Edmunds, Beutels and Smith (2008) assert that in response to the rapid spread of influenza amongst learners, the policy that may be most likely to be introduced to mitigate disease spread is school closure. Dense gatherings of learners at school enable rapid transmission of diseases. Murphy (2020) concurs that the COVID-19 pandemic quickly led to the closure of universities and colleges around the world in the hope that the public health officials' advice of social distance could help to flatten the infection curve and reduce total fatalities from the disease. Zimbabwe, like other countries in the world, followed a similar route of the closure of universities, colleges and schools. 
The indefinite closure of schools has led to home schooling. According to Bohon (as cited in Moreau, 2012, p. 7), "Home schooling means being taught at home, but the education is provided by a public school system via the internet or correspondence. Parents are strictly mentors." For someone to be able to teach effectively, there is need for teacher training. According to Boudersa (2016) teachers at all levels need to be trained in their related fields and subject matter. However, suddenly parents found themselves having to take the position of a teacher, in enforced online home schooling.

This research was based on Vygotsky's (1978) Social Constructivist Theory which emphasises that knowledge is reciprocally built and constructed, and the development of cognition is greatly supported by social interaction. The strength of the theory is on social interaction, socio-cultural activity and collaboration or assisted performance. Vygotsky suggests that as learners interact with others, they are exposed to sharing of views and ideas which result in understanding of concepts (Kalpana, 2014). The principle of more knowledgeable other (MKO) who could be a teacher, coach, older adult, peers, a younger person, or even computers proposes that MKO should be an individual who is better informed than the learner regarding the task, process or concept to be performed (Vygotsky, 1978). The theory further brings about the principle of zone of proximal development (ZPD) which is the distance between a learner's ability to perform a task under adult guidance and/or with peer collaboration and the learner's ability to independently solve the problem. Thus, the potential for cognitive development depends upon this zone where learning occurs (Vygotsky, 1978).

\section{METHOD}

The study was premised in the interpretive paradigm and a qualitative approach. Ten purposively selected parents in the Bulawayo Metropolitan Province were the key informants. The qualitative approach was selected in order to obtain rich data from the participants (Cooper \& Schindler, 2008). Data which was collected using emailed openended questionnaires was transcribed and thematically analysed. The themes came out as a result of intense reading of the participants' scripts. Regarding ethical considerations, full disclosure of purpose of data collection, non-coercion of participants and non-disclosure of participants' identities were observed (Bryman, Bell, Hirschsohn, Dos Santos, Du Toit, Masenge, Van Aardt \& Wagner, 2017).

\section{RESULTS}

To fully understand the participants in the context of the study, an analysis of demographic data pertaining to gender, age, number of school going age children and the employment status of parents was done. The findings are shown in Table 1.

\section{Demographic Data}

Table 1: Demographic profile of the participants $\mathrm{N}=10$

\begin{tabular}{lc}
\hline Gender of participants & \\
\hline Male & 4 \\
Female & 6 \\
Total & $\mathbf{1 0}$ \\
\hline
\end{tabular}

\begin{tabular}{ll}
\hline Age range & \\
\hline 30 years and below & 1 \\
$31-40$ years & 6 \\
$41-50$ years & 2
\end{tabular}


$\begin{array}{lc}51+\text { years } & 1 \\ \text { Total } & 10\end{array}$

\begin{tabular}{lc}
\hline Number of school going children & \\
\hline None & 0 \\
One & 3 \\
Two & 4 \\
Three & 1 \\
Four and above & 2 \\
Total & $\mathbf{1 0}$ \\
\hline
\end{tabular}

\begin{tabular}{lc}
\hline Number of working parents & \\
\hline Male & 4 \\
Female & 6 \\
Total & $\mathbf{1 0}$ \\
\hline
\end{tabular}

The study revealed that there were more female than male participants. Similarly, there were more working female participants than male. These results imply that with home schooling, female participants were bound to have more responsibilities than men. Regarding the age range, there were more young parents in the 31-40 years age group, than any other age group. One would expect this age group of parents to be technologically savvy and face minimal challenges with online home schooling. The numbers of school going age children were manageable, suggesting that parents would not face as many challenges as would one with more children.

\section{Requirements for Conducting Online Lessons}

Participants were asked to list the resources that were needed to conduct online lessons and whether they had the relevant skills. These are shown in Table 2.

Table 2 shows requirements for online lessons $\mathrm{N}=10$

\begin{tabular}{lcc}
\hline Statement & Yes & No \\
\hline Do you have a laptop? & 10 & \\
Do you have a smart phone? & 10 & \\
Do you have internet services? & 8 & 2 \\
Are you computer literate? & 10 & \\
Do you have a teaching background? & 10 & \\
\hline
\end{tabular}

According to results in Table 2, most parents had the necessary requirements to conduct online lessons except for two who did not have internet services. These results are an indication of affluent and knowledgeable parents who should experience minimal challenges in conducting online lessons.

\section{Platforms Used for Online Lessons}

The information gathered revealed that seven out of ten parents indicated that their children were learning online using platforms which included WhatsApp, Ruzivo, Google Classroom, Google Meet, Zoom, YouTube and Microsoft Teams. The subjects taught involved Mathematics, Science and Technology, Heritage Studies, English, Music, Information and Communication Technology, Ndebele, Agriculture, Geography, Family, 
Religion and Moral Education (FAREME). Most of the children were of primary school going age and a few were at secondary school hence some of the subjects shown below.

Parent 6: History and Commerce

Parent 8: Mathematics, Science and Technology

Parent 9: Mathematics, English, Ndebele, French, Geography, Design and Technology, History, Art, Principles of Accounts, Science, Physical Education, Religious Education, Computers and AutoCAD

When asked which subjects they could confidently teach their children, most of the participants indicated that they could teach Mathematics together with other subjects. Examples of their responses are as follows.

Parent 1: Mathematics, Science and Accounting

Parent 3:Mathematics, Science, Information Technology, Agriculture and Geography

Parent 9: Principles of Accounts, English, Ndebele, Religious Education, Science and Mathematics

Parent 10: Mathematics, English, Art and Computer

However, Parents 4 and 7 seemed to have challenges with the teaching of Mathematics either at primary or secondary level as they indicated that they assisted their children in the subjects stated below.

Parent 4: Ndebele, English, Religious and Moral Education and Heritage Studies

Parent 7: Ndebele Language. Ndebele Literature and English Language.

The participants' responses suggest that they were involved in online home schooling as they were assisting their children in most of the subjects.

\section{Challenges Experienced by Parents in Conducting Online Lessons for their Children}

To establish if parents were ready for online lessons, they were asked whether they had experienced any challenges in conducting the lessons. Their responses revealed that parents encountered various challenges which encompassed lack of expert knowledge in the subject matter, lack of skills in teaching some of the subjects, in some cases problems in using the specified software and inadequate time to teach all the subjects. Some of their responses are espoused below.

Parent 1: I have challenges in supervising Geography, History, and Agriculture because it has been a long time since I last did these subjects. Besides, the syllabi have changed.

Parent 5: I have challenges with Performing Arts, Music, Art, Ndebele and Library. This is because I do not have the skills for them, and even during my school days, I did not do these subjects.

Parent 9: I have challenges in teaching subjects such as French; I fail to comprehend the instructions before I even go to the content. Design and Technology, the terminology for the subject sometimes confuses me a lot. History, I never did History at school and I never liked the subject. AutoCAD, I am used AutoCAD 2007, whereas the school is using AutoCAD 2020. Initially I had problems in installing the software. Computers, I am not familiar with the component that they are doing, 
especially when they are doing computer programming because I have never done it in my lifetime.

Parent 10: Ndebele, Family Heritage, RME, Science, Music and PE. They are time consuming as I will also be having work to do. They require more time for guided learning.

Parents were also asked to list the practical subjects that they had to teach online and explain how they did it. This is what some of them said:

Parent 1: I teach Science and Technology, Agriculture, Music and Heritage, I draw and show her pictures of the apparatus used in experiments. I also rely on google for a subject like Music so that she can hear the sounds and notes.

Parent 4: Music, Computers. We just follow the instructions given via audio and video.

Parent 7: Practical subjects need more time and they require a lot of data. It is sometimes difficult to explain some concepts online. Face to face interactions are convenient for practical subjects. We just follow the instructions given by the teacher.

Parent 9: I teach Science, the child performs and records simple experiments following sent guidelines then submit through Google classroom platform. In Art, I assist my son to draw, scan and send work online for marking. As for AutoCAD, drawings are done offline whilst the child answers the questions asked on different measurements which they would be asked to calculate on the Google classroom platform. In this case the quiz section is used. After recording our answers, we receive immediate feedback.

From the presented data, it is evident that most of the parents are finding it difficult to assist their children in learning practical subjects online. Though they had the necessary equipment to conduct online lessons, they do not have expertise to teach practical subjects. When asked what further challenges they experienced in conducting online lessons, the participants gave a plethora of constraints they encountered during home schooling using online learning platforms. They mentioned the prohibitive cost of Wi-Fi bundles, lack of adequate power supply, too much workload from teachers, lack of expertise in use of online platforms from some of the teachers, some teachers not giving clear instructions on what is supposed to be done, sharing of online devices and commitment of parents to other responsibilities. The following experiences were mentioned as evidence of what parents were going through.

Parent 2: There is too much workload from teachers. Teachers send lots of new concepts introduced one after the other. Teachers seem to be in a hurry to complete the syllabus. Sometimes the teachers concerned are not there to assist parents. They just post work and go offline. Some of the work needs printing but $l$ do not have a printer. I end up manually drawing the diagrams to assist the child to understand the concepts.

Parent 8: Internet connectivity is poor. Data bundles are costly and we also experience power cuts.

Parent 9: To start with, teaching online is very expensive. I have two boys both doing online lessons. They are both doing twelve subjects. On average a day we use about 5 gigabytes or more if there are videos sent and Zoom 
classes. The cost of data goes up unexpectedly, so when bundles are finished, purchasing another lot becomes a nightmare. Some teachers do not spell out the instructions clearly. If it is one of the subjects that I am not well versed with, we always have problems in coming up with solutions. I only have one laptop and two online learners. Some of the due dates would be on the same day, so we fail to meet the deadlines because we do not have enough gadgets. Network problems are on the rise. The service provider we use is not efficient, so we have since bought another line from a different service provider which we use from 6pm onwards and that is an extra cost. Monitoring Google Classroom work is problematic, especially when you are always preoccupied. The child can decide to deliberately miss some assignments. I always check on weekends only to find many missing assignments. Sometimes teachers send assignments with same deadlines and it becomes stressful as we work until late at night. Some teachers are not computer literate. When we send assignments we only get the marks. We cannot view the marked assignment so that we see where we went wrong.

The participants' responses indicate that the selected parents had difficulties in assisting their children learning online. It came out that some teachers sent a lot of work to their learners whilst others could not give immediate feedback so that parents could check if they were correctly helping their children. There is evidence from the responses that some parents are overwhelmed by online home schooling during COVID-19 lockdown.

\section{Intervention Measures Taken by the Schools to Mitigate the Resistances and Challenges Faced by Parents and the Usefulness of the Measures}

Parents were asked to explain whether schools had taken any measures to mitigate the resistances and the challenges that they faced. In response, some participants mentioned that the schools which their children attend. negotiated with internet service providers to enable their learners to access affordable data bundles. In some cases, the information and technology technicians and teachers were always available on line to assist learners and parents who experienced connectivity problems. Through emails sent to the parents. Teachers also monitored if learners were doing the given tasks. Additionally, some schools would allow their learners to access school Wi-Fi at no cost. Another measure taken by some schools was to minimise the use of online platforms that consume a lot of data bundles. However, it was established that in some schools there were no intervention measures offered. The parents would bear all the costs for online lessons. Some of the participants' responses were as follows.

Parent 1: The school has a facility that learners access discounted Wi-Fi from one of the internet service providers. To clarify some concepts, teachers provide audio/video together with word documents. Their learners are also given 24 hours to submit their work.

Parent 3: Information and Technology technicians and teachers are very helpful with connection problems and advice on how to use laptops and tablets. The school also facilitated a platform to access data for the teachers and parents from various internet service providers.

Parent 5: They give me data bundles though limited. They allow me to also use school Wi-Fi at no cost. 
Parent 9: The school organised with a particular service provider to avail to parents educational data bundles of 20 Gig for a reasonable price. So we were given certain days when we should make payments to that service provider and get the bundles. The teachers would check the learners' work to identify those not handing in assignments and as parents we are sent emails. The school has resolved that they send minimal videos and minimise Zoom classes as they consume a lot of data bundles.

Nevertheless, some participants revealed that the schools which their children attend did not support online learning at all. This what they said:

Parent 4: The school gives us nothing, except telling us to be patient.

Parent 6: The school has never accorded us with the online learning platform. I only heard about online lessons through WhatsApp and those offering are very expensive.

The data presented revealed that some schools support online learning in various ways despite the challenges experienced whilst others left all the burden to parents. This suggests that the parents who got support from schools actively participated in online learning of their children. On the other hand, those parents who were not assisted by the schools found it difficult to help their children with school work during COVID-19 lock down.

It was also necessary to find out from parents if they had found the measures taken by the schools helpful. It came out from the participants that the measures taken by schools were beneficial to both the parents and their children. The measures enhanced online learning. Nonetheless, not all parents were happy with the measures taken by the schools. For example, lack of assistance from the school and disruption of internet connectivity inhibited effective conducting of online lessons during COVID-19 lock down. The responses given by some of the participants were as follows.

Parent 2: Yes, because whichever route, our children benefit from the exercise.

Parent 9: Their suggestions have been very useful. Organising the data bundles deal was a great saving. Instead of getting the same bundles at a higher price we got it at a discount. Again, checking of learners' assignments helps us a lot especially if a parent is busy all day.

Parent 10: The smart television issue worked but additional devices such as a mouse and keyboard were required, but it works.

However, those parents who did not benefit from the measures taken by the schools expressed the following sentiments.

Parent 4: Not really because internet is not stable.

Parent 7: The school has not helped at all.

The participants' views indicate that those parents who got support from the schools appreciated the measures taken by the schools whilst other parents were not satisfied with what was done by the schools which their children attend.

\section{How Online Lessons Conducted by Parents for Their Children were Beneficial}

Parents were asked whether despite the challenges faced they found the lessons beneficial for their children. Most of the participants were positive about the participation of their children in online lessons. They expressed that online lessons kept their children occupied with school work as they were continuing with the syllabi, the parents were involved in 
their children's learning, children developed computer skills as they operate the electronic gadgets they use for online lessons, the timetabled online lessons have instilled discipline among their children as they know what to do at any given time. Feedback from teachers was also valuable to both parents and their children. Though some parents were delighted about online lessons others felt that there was no proper learning taking place online. Some parents were not always available at home to monitor their children during online lessons. Examples of their responses are stated below.

Parent 1: Yes, he is not idle. Three months is too long doing nothing at home. There is continuity from the concepts learnt before lockdown. Syllabus is being covered.

Parent 2: Yes, they learn and revise learnt work. They are also kept busy with school work.

Parent 3: Yes, we have covered a few topics very well and those with home assistance get to benefit from the one-on-one interaction with their guardians as well.

Parent 5: Yes, she gets the motivation to focus on her school work instead of playing all day. She also gets excited to be taught by a parent, something she never imagined as she always asks, "Are you a teacher now?" Above all, she has learnt new concepts she would otherwise not have learned had the online lessons not been introduced.

Parent 8: Yes, the children develop the computer literate skills and develop fine motor skills.

Parent 9: Yes, there is some bit of continuity. They are kept busy during the lockdown. The lessons are timetabled. The children are now disciplined. They know that at this particular time, a particular lesson would be ongoing. Every time they miss assignments, an email is sent to me. This makes them very vigilant always. The boys have gained some research skills. I hope when they finally open they will continue working the way they have been doing.

Parent 10: Yes, lessons are well explained with the use of audios, videos, pictures and text. There is feedback on the assessments done though some will not physically show where the child has to correct.

Despite the positive remarks given by some participants, others expressed dissatisfaction regarding conducting online lessons during COVID-19 lock down. This is what they said:

Parent 4: No, there are too many distractions at home. As a working parent, I am not always at home to monitor their learning progress.

Parent 7: No, there is no proper learning taking place as no one monitors online learning.

There is evidence from the information presented that most of the parents realised the positive results of online learning. However, some parents indicated that online learning had negative effects on their children since there was no monitoring during the lessons.

\section{Lessons for Parents and Educators Derived from the Corona Virus Pandemic Lock Down}

Although COVID-19 is taken to be a pandemic that caused global havoc, there are lessons that can be derived from it. The participants were asked to shed light on the lessons derived 
from COVID-19 lock down. The responses showed that there was need for the government to provide resources for online learning to cater for all learners. Parents should be equipped with teaching skills to assist their children in home schooling. Parental involvement in their children's learning is critical. Both parents and learners should be computer literate. Parents had an obligation to provide online learning resources at home. The education system should adopt technological based instructional delivery. Below are some of the views of the participants.

Parent 1: Parents need to be equipped with teaching skills.The government must intervene in providing or sourcing the required equipment to assist in online learning.

Parent 2: When in a crisis, it is good to do the best you can when teaching children and learn to be adaptable. Some days, you cover less than on the normal school day. This is the reality of a crisis. Keeping your mental health and that of the children is more important than stressing over an unattainable normalcy. Working is as a team especially between the home and the school is the best tool for educational progress.

Parent 4: That conventional school is important and teachers should be greatly valued for their hard work. Also, that there is more we can do as parents to assist our children rather than leave it to the school and teachers. It also made us understand our children better in terms of their subjects, their strengths and weaknesses and also in terms of their passions, hence we are in a better position to support them.

Parent 6: I have learnt that it is important for both parents and learners to be computer literate. We should invest in providing our children with gadgets that assist them in e- learning. Wi-Fi is a necessity at home as it accords our children access to online lessons.

Parent 8: There is need for technological advances in education.

Parent 9: The society should equip itself with ICT skills and try to acquire gadgets that will enhance learners to use e-learning. The educational system should improve the learning processes, having more of technological based instruction. This will assist when an unexpected pandemic like COVID-19 strikes.

The participants' insights suggest that online home schooling yielded positive results such as active participation of parents in their children's learning. This enlightened the parents on the strengths and weaknesses of their children in various subjects. Hence, parents were aware of the learning resources needed by their children. Through online learning, both parents and their children acquired some skills on how to use technological tools.

\section{DISCUSSION}

The study established that most of the parents were involved in online home schooling as they were assisting their children in most of the subjects taught at school. It came out of the findings that various online learning platforms such as WhatsApp, Ruzivo, Google Classroom, Google Meet, Zoom, YouTube and Microsoft Teams were used in delivering lessons. The findings are in line with the study conducted by Duraku, and Hoxha, (2020) in Kosovo where it was found that learning platforms such as Google Meet, Zoom, Google Classroom, Viber and WhatsApp were used to conduct remote or online learning. The results further revealed that most parents were confident in teaching mainly Mathematics while a few had challenges either at primary or secondary level. 
The findings of the study revealed that parents encountered various challenges as they embarked on online home schooling. The challenges encompassed lack of expert knowledge in the subject matter and lack of skills in teaching some of the subjects. In some cases they had problems in using the specified software and inadequate time to teach all the subjects. The results of the study also indicated that most of the parents were finding it difficult to assist their children in learning practical subjects on line. Though they had the necessary equipment to conduct online lessons, they did not have expertise to teach practical subjects. The findings of the current study confirm Green's (2005) observation that for home schooling to be successfully implemented, parents should possess the skills necessary for teaching their children, such as knowledge about learning events that may enrich their child's education, teaching methods, and subject matter.

It further came out from the findings that there were some prohibitive constraints which hindered effective implementation of online home schooling. These included high cost of Wi-Fi bundles, inadequate power supply, sharing of online devices and commitment of parents to other responsibilities. The findings are contrary to what was found in Kosovo by Duraku, and Hoxha, (2020) where the results showed that learners possessed sufficient technological equipment, including smartphones, computers, laptops, and iPads, which ensured their participation in online learning during COVID-19 lock down.

The results also showed that parents lamented about too much workload from teachers and lack of expertise in use of online platforms on the part of some teachers. Other teachers were not giving clear instructions on what was supposed to be done, and some were not giving immediate feedback so that parents could check if they were correctly helping their children. The findings are in agreement with Duraku, and Hoxha's (2020) findings that the teachers who participated in their study in Kosovo had no previous experience in conducting online learning. The results of this study further support the findings of the study conducted in Czech by Brom, Lukavský, Greger, Hannemann, Straková, \& Švaříček, (2020) who established that teachers most often assigned tasks, but to a lesser extent explained tasks or actually taught subjects. However, the findings of this study contradict what is suggested by social constructivist theory principle of more knowledgeable other (MKO) who should be better informed than the learner regarding the task, process or concept to be performed (Vygotsky, 1978).

The study revealed that there were numerous measures taken by some schools to mitigate the resistances and the challenges that the parents faced in conducting online home schooling during COVID-19 lock down. It was mentioned by some parents that the schools which their children attended, negotiated with internet service providers to enable their learners to access affordable data bundles. In some cases the information and technology technicians and teachers were always available online to assist learners and parents who experienced connectivity problems. Through emails sent to parents, teachers also monitored if learners were doing the given tasks. Additionally, some schools would allow their learners to access school Wi-Fi at no cost. Another measure taken by some schools was to minimise the use of online platforms that consume a lot of data bundles. However, it was established that in some schools there were no intervention measures offered. The parents would bear all the costs for online lessons.

It came out from the findings that the measures taken by some schools enhanced online learning and were beneficial to both the parents and their children. Nonetheless, not all parents were satisfied with the measures taken by schools which their children attend. It was highlighted that lack of support from the schools and disruption of internet connectivity inhibited effective conducting of online lessons during COVID-19 lock down. 
The study further established that most of the selected parents were positive about the participation of their children in online lessons. It was found that online lessons kept their children occupied with school work as they were continuing with the syllabi. Parents were involved in their children's learning. Children developed computer skills as they operated the electronic gadgets they use for online lessons. Timetabled online lessons had instilled discipline among their children as they knew what to do at any given time. Feedback from teachers was also valuable to both parents and their children. These results are consistent with Vygotsky's (1978) social constructivist theory which underscores that knowledge is reciprocally built and constructed, and the development of cognition is greatly supported by social interaction. It was revealed that though some parents were delighted about online lessons, others felt that there was no proper learning taking place online. Some parents were not always available at home to monitor their children during online lessons. This finding is commensurate with United Nations' (2020) observation that children's dependence on online platforms for distance learning has also increased their risk of exposure to inappropriate content and online predators.

This study also indicated that there were innumerable lessons derived from online home schooling during COVID-19 lock down. It came out from the findings that online home schooling yielded positive results such as active participation of parents in their children's learning. This enlightened the parents on the strengths and weaknesses of their children in various subjects. Hence, parents became aware of the support and learning resources needed by their children. Through online learning, both parents and their children acquired some skills on how to use technological tools.

\section{CONCLUSION}

The study examined how online home schooling was conducted by selected parents during COVID-19 lock down. The results of the study revealed that most parents assisted their children in various subjects taught at school through the use of several online learning platforms such as WhatsApp, Ruzivo, Google Classroom, Google Meet, Zoom, YouTube and Microsoft Teams. However, the selected parents encountered quite a number of challenges which included lack of expert knowledge in the subject matter, lack of skills in teaching some of the subjects, as well as use of specified software and inadequate time to teach all the subjects. Notwithstanding the challenges experienced by selected parents, the study concluded that online home schooling yielded positive results such as active participation of parents in their children's learning. This enabled parents to identify the strengths and weaknesses of their children's learning in various subjects and provided necessary support and resources. Online learning resulted in both parents and their children acquiring some skills on how to use technological tools.

\section{REFERENCES}

Brom, C., Lukavský, J., Greger, D., Hannemann, T., Straková, J., \& Švaříček, R. (2020). Mandatory Home Education during the COVID-19 Lockdown in the Czech Republic: A Rapid Survey of 1st-9th Graders' Parents Frontiers. Retrieved from: http://www.researchgate.net/publication/340738244

Bryman, A., Bell, E., Hirschsohn, P., Dos Santos, A., Dutoit, J., Masenge, A., Van Aardt, I., \& Wagner, C. (2017). Research methodology: Business and management contexts. ( $7^{\text {th }}$ Ed.), Cape Town: Oxford University Press.

Comer, J. P. \& Haynes, N. (1997). The Home-School Team: An Emphasis on Parent Involvement. Retrieved from: http://www.edutopia.org/home-school-team 
Cooper, D. R. \& Schindler, P. S. (2008). Business Research Methods. Singapore: McGrawHill.

Doepke, M. \& Zilibotti, F. (2020). COVID-19 and Children's Education: Love, Money and Parenting. Retrieved from: https://www.psychologytoday.com/intl/blog/love-moneyand-parenting/202004

Duraku, Z. H. \& Hoxha, L. (2020). The impact of COVID-19 on education and on the wellbeing of teachers, parents, and students: Challenges related to remote (online) learning and opportunities for advancing the quality of education. Retrieved from: http://www.researchgate.net/publication/341297812

Flack, C. B., Walker, L., Bickerstaff, A., Earle, H., \& Margetts, C. (2020). Educator Perspectives on the Impact of COVID-19 on teaching and learning in Australia and New Zealand. Retrieved from: https://www.pivotpl.com.Pivot_State of Education_2020_White-Paper.pdf 1-38.

Green, C. L. (2005). Home-Schooling as an Extreme Form of Parental Involvement. Master's thesis, Vanderbilt University, Nashville, United States of America.

Kalpana, T. (2014). A constructivist perspective on teaching and learning: A conceptual framework. Institute of educational technology and vocational education. Panjab University, International Research Journal of Social Sciences, 3(1), 27-29.

Kazunga,O.(2020).COVID-19 pulls down OK. Retrieved from: https://www.chronicle.co.zw/covid-19-pulls-down-ok-volumes

Keogh-Brown, M., McDonald, S., Edmunds, W. J., Beutels, P., \& Smith, R. D. (2008). The Macroeconomic Costs of a global influenza pandemic. Retrieved from: www.indexinvestor.com

McCracken, N. (2020). Coronavirus: Is home schooling working for children?. Retrieved from: https://www.bbc.com/news/av/uk-northern-ireland-52582610/coronavirus.

Moreau, K. (2012). Home schooled vs Public schooled. Specific differences in the Educational Outcomes of those students who are home schooled vs students in a traditional school setting. Master's dissertation, Northern Michigan University, Michigan, United States of America.

Murphy, P. A. (2020). COVID-19 and Emergency eLearning. Consequences of the securitisation of higher education for post-pandemic pedagogy. Journal of Contemporary Security Policy, 41(3), 492-505.

United Nations (2020). Policy Brief: The Impact of COVID-19 on Children. Retrieved from: https://unsdg.un.org/sites/default/files/202004/160420_Covid_Children_Policy_ Brief.pdf

Vygotsky, L. S. (1978). Mind in society: The development of higher psychological processes. Cambidge, MA : Harvard University Press. 